\title{
Urban imaginaries and the sustainable city
}

\author{
S. Mejía-Dugand, O. Hjelm \& L. W. Baas \\ Environmental Technology and Management, \\ Linköping University, Sweden
}

\begin{abstract}
This paper discusses the case of Medellín, a city that has received international attention in recent years due to its improvements in social and environmental aspects. The process of selection and implementation of foreign technologies for the achievement of collective goals such as sustainability in the city and how it is affected by the interaction between local and foreign urban imaginaries is discussed. The case of a waste management systems provider operating in an urban renewal project taking place in the city is presented. The importance of solid proof-of-concept projects that facilitate the understanding of the contribution of certain technologies to local goals and the transmission of crucial information is analyzed. It is found that besides cultural and political links, Medellín has found similarities regarding urban planning directives in Spanish cities where the system is implemented, and technical and emotional support to undergo its infrastructure transitions.

Keywords: environmental technologies, proof-of-concept, urban sustainability, local stakeholders, foreign technologies.
\end{abstract}

\section{Introduction}

Cities are expected to be places for the practice of democracy and for the construction of social equality and inclusion (Peñalosa [1]). This is also true for sustainability (Bulkeley and Betsill [2], Vojnovic [3]). Participation in the formulation of collective goals such as urban sustainability is thus central, because of the shared nature of the urban environment (Hillman et al. [4]). By itself, the term "urban sustainability" is bound to a geographically defined area, i.e. the city and, although not always the case, its surroundings. This fact makes the definition of the practical contribution of cities to global sustainability a difficult enterprise. In addition, there is no transnational urban sustainability language, as this is 
dependent on temporal and spatial perspectives (Hult [5]). Separate entities (in this case cities) working on their own have fewer opportunities to achieve goals that require coordination, since unilateral efforts have a small chance of success (Hansson [6]).

Although achieving sustainability to a large extent requires change in the lifestyles of citizens (e.g. consumption patterns, waste generation, fossil-fuel use, etc.; see e.g. Shove and Walker [7]), technology and science are trusted by many to support this pursuit, and neutralize the effect of human activities by offering non-declining per capita consumption (see e.g. Ayres et al. [8], Cabeza-Gautés [9], Huesemann and Huesemann [10]). Considering the central role that technology plays in everyday urban life and the scale of coordination needed in modern cities, it is important to keep in mind the need to mix both approaches, and recognize the important foundations that technology has laid for the achievement of sustainability goals. Discussions of sustainability transitions that do not envision the links between existing and imagined societies fail to reinforce the required change (Boonstra and Joosse [11]).

In this paper, we explore how urban sustainability imaginaries (i.e. collective visions or understandings of what a sustainable city is) are constructed, influenced by technology and science. In this line, we discuss how the search for urban sustainability has created a highly competitive international market, which we will call the "sustainable city market." We refer to cities that are facing a sustainability problem and are looking for a technological solution in this market, or to those that are seen by foreign suppliers as potential adopters of their technologies, as "cities-customers." With this in mind, we aim to answer the following questions: How does the process of selection and implementation of foreign technologies happen in cities-customers? How is this process affected by the interaction between local and foreign urban imaginaries?

We discuss the case of Medellín, Colombia. The city has relatively recently received international attention due to its improvements in social and environmental aspects. Many of these improvements have relied on a stable source of revenue: the city's utility company, which has enabled the city to increase its spending on social and environmental projects impressively during the last two decades. The paper is structured as follows. Section 2 discusses how societies shape an understanding of collective problems and agree on mechanisms to face them, while Section 3 describes the methodology. Section 4 describes and discusses the case of Medellín and its utility company, and Section 5 describes an urban renewal plan in the city. Section 6 presents the case of a foreign waste management systems provider involved in this plan and its reliance on adequate showcase cities to aid the alignment of its technology to local conditions. Section 7 discusses the importance of showcase cities for the diffusion of environmental technology, and Section 8 presents the conclusions.

\section{Collective goals and actions}

Each society forms an image or understanding of how the problems it faces affect it and how they can be solved. In particular, participation is important when such 
an image affects collective goals such as sustainability (Geels [12]). For this, Hillman et al. [4] suggest, societies can make use of cognitive (values and perceptions that define a problem and the required structures to deal with it) and normative (how a common goal, understanding, and agreement on the desired outcome are formed) governance mechanisms.

A strong technocentric view on how cities-customers' environmental problems can be solved often dictates foreign strategies to diffuse their technological solutions to other cities (Mejía-Dugand [13]). This view has the risk of reducing the discussion of how cities contribute to global sustainability to administrative terms, e.g. architectural design, traffic management, and the use of renewables (Bulkeley and Betsill [2], Hodson and Marvin [14]). In fact, the sustainable city market inundates cities-customers with images, concepts, facts, policies, behaviors, and especially technologies that, although developed under foreign socio-political and techno-scientific conditions, promise to alleviate their problems without major contextual considerations (Hult [5], Wangel [15]). This is a double-sided promise: suppliers also expect to benefit from receiving a share of the growing global market in environmental technologies (Hult [5], Kanda et al. [16], Van der Slot and van den Berg [17]). However, when people, space and time are left out of the analysis of cities and their interaction with technology, results tend to be fruitless (Mejía-Dugand [13], Rutherford [18]).

Such external influences are evident in the modern city, which, according to Rutherford [18] is "an assembled space of parts of other places." This view suggests either the exertion of power (e.g. through colonialism or authoritarianism) or the exercise of learning and adaptation (see e.g. MejíaDugand et al. [19]). The former does not necessarily clash with the achievement of goals such as urban sustainability, since change is exerted through governance (van der Heijden [20]), and governance and democracy are not necessarily supportive: an authoritarian regime could govern effectively, just as a democracy could be maladministered (Fukuyama [21]). The latter, however, interests us more since under this view urban sustainability is seen as a collective goal, one in which all stakeholders have a say (see e.g. Peñalosa [1]). In particular, learning and adaptation processes are important when analyzing the role that technology plays in the pursuit of urban sustainability. Modern cities inevitably see technology as a foundation for the improvement of their reputation and their citizens' living conditions (Bulu [22], Hodson and Marvin [14]), and as a way to publicize themselves in national and international markets, where they compete fiercely for resources (DiGaetano and Strom [23], Timms [24]). In this sense, societies must develop new governance tools to respond to external pressures from these markets (Hodson and Marvin [14]): cities normally compete for resources under freemarket conditions, and these pressures often leave little room for long-term environmental goals (Polk [25]).

Which governance mechanisms can support the learning and adaptation process needed to face urban sustainability challenges? Society has to agree on what the problem is and on the networks needed to build the required knowledge to solve it (Hillman et al. [4]). The definition of the problem is highly dependent on local conditions and values (Smith and Stirling [26]). Although cities can and 
do learn from other cities' good and bad experiences (Mejía-Dugand et al. [19], World Business Council for Sustainable Development [27]), they also need to perform their own experiments, monitor and evaluate these experiments, and adjust the strategy based on the results (Loorbach [28]). When innovations are compatible with existing values and systems, and are easy to understand, they are more easily implemented (Rogers [29]). This is supported by the work of Oettingen and Mayer [30] and Kappes and Oettingen [31], who found that thinking about idealized futures is an energy-demanding process, and that when these imaginaries are disconnected from past experience and existing systems, the result is less effortful action, poorer performance, and reduced well-being, since the risk of missing out on important obstacles and hindrances is higher.

When a certain society agrees on collective goals, such as sustainability, it also has to decide if these goals are to be achieved through means found in paradigmatic ideas of sustainable cities, or through vehicles that first assure compatibility with local conditions and stakeholders (Mejía-Dugand et al. [19]). As discussed above, suppliers driven by technocentric motivations might offer solutions in isolation from contextual requirements, very much like car producers that offer endless comfort without considering that external factors such as traffic and overcrowding might play an even more important role. In addition, when a certain system fails, not only technically, but in connection with coexisting and often interconnected systems, cities will be left with a technological dependence that most stakeholders will not appreciate (Mejía-Dugand et al. [19]). It might thus be easier for cities to engage in socio-technological change when they can find experiential, technical and moral support to undertake technological implementations, especially when they are transversal to different areas and groups in the city (Mejía-Dugand et al. [19]). This support is most efficient when found in societies that are more culturally compatible, since interaction and the strengthening of the networks through which essential knowledge spreads are facilitated, and less energy is needed for sharing information (Rogers et al. [32]).

\section{Methodology}

Between 2013 and 2014, we made field trips to the city of Medellín in order to visit various infrastructure projects and conduct a set of interviews with different stakeholders within city and county government and the municipal utility company. In particular, we were interested in an urban renewal project taking place in a central area of the city. This area is called Naranjal, and is considered a strategic location due to its high value and close connection to city services. The area consisted mainly of heavy and lightweight vehicle repair workshops and a network of small businesses revolving around informal waste picking and recycling activities. There were also residential buildings.

The city is undertaking a project to revitalize the area by building new residential and commercial buildings with the intention, among other things, to densify the city center, and connect it to a plan to recover the river that dissects the city and runs south to north of the valley where it is located. We therefore interviewed the subdirector of the Housing Unit at Empresa de Desarrollo Urbano 
(EDU), the governmental agency in charge of the execution and development plans approved by the city's government, such as the plan in Naranjal. Our interest in this area is justified by the presence of Envac, a Swedish technology supplier of underground waste management systems involved in this project. In addition, we interviewed the former CEO and the head of the Waste Management Unit at the local utility company, as well as the subdirector of the Planning Department and the director of the Strategic Planning Unit at the county administration. We also conducted additional interviews with Envac's CEO and some representatives of the company in Spain, who are in charge of administering the relations with Medellín. In April 2015, we visited different projects in Madrid and Barcelona, where Envac's system has been implemented, and interviewed actors from the city's administration that were involved when the system was first implemented there.

Finally, we performed archival work on the city of Medellín, its utilities infrastructure development, and the history of its utility company, in order to better understand the emergence of this central actor and the power relations in the city. Local libraries were used to perform the archival work, and a local university provided additional recorded interviews in which former employees of the utility company and other academics discussed the history and evolution of the company. The information collected from the interviews was transcribed and analyzed together with information found in historical records and recorded interviews. In this way it was possible to better understand the important role that the municipal utility company has in the city, and how the city generates resources to undertake major infrastructure projects. Interviews with Envac provided a different perspective and allowed us to understand the hindrances that foreign urban imaginaries and the technologies that are often connected to them face.

\section{The city's utility company as an important factor in the city}

The city of Medellín is a special case when it comes to its utilities (Furlong [33]). Empresas Públicas de Medellín (henceforth referred to as EPM), the city's multiutility company, was founded in 1955 with the intention to unify and administer the public services of electricity, telephone service, drinking water and sewage. The company had to be of an "apolitical nature, ruled by a rigorous administrative efficacy criterion, for which the adequate technical systems for corporate organization must be used" (The Colombian Government [34]). The company was also authorized to provide its services to municipalities outside the city's administrative boundaries, only "if by doing so, the fulfilment of the needs of the City of Medellín and its citizens or companies are not jeopardized; these have to be prioritized" (The Administrative Council of the City of Medellín [35]).

The liberalization of the utilities market in Colombia in 1994 opened the door to privatization. Although some Colombian cities decided to list their companies on the stock exchange, Medellín opted to convert the company into a State Industrial and Commercial Company, a legal concept promoted by politicians from the region where the city is located. Such a concept allowed the municipality 
to retain full ownership of the company, but govern it under private rather than public law. The company has benefitted from the mountainous geography of the region where it operates, since hydroelectric power from water dams is one of its main sources of revenue (Furlong [33], Varela Barrios [36]). Following its expansion goals and because of local market saturation, the company has expanded its operations to national and international markets (Furlong [33]). The company operates now in six Latin American countries, USA and Spain, and has the ambitious goal of having 40\% of its commercial activities abroad by 2015 . While the company transferred roughly USD 21 million to the city of Medellín in 1997, that figure grew to USD 446 million in 2010, resources that represent around one-third of the city's budget today (Vélez Álvarez [37]). By law, the company cannot transfer more than $30 \%$ of its profits to its owner. However, the city formally authorized in 2007 extraordinary transfers, designated solely for specific social programs, and after the proper analysis of the company's financial viability. Since then, the city's spending on social projects has increased by $129 \%$ (Furlong [33]).

EPM, protected by national laws, had the monopoly for the provision of public services in the city until the market liberalization law in 1994. However, EPM took advantage of natural monopoly conditions and is today the largest actor in the sector. In addition, its ability to generate revenue, operational efficiency, technical expertise and the strong sense of belonging it has managed to create in citizens (see e.g. Furlong [33]), have made it an unavoidable force to reckon with when planning for infrastructure interventions. In fact, one of the interviewees from the county administration said when discussing underground systems: "EPM thinks they own the underground (because most of the infrastructure laid there is theirs), but in reality the underground belongs to the state." EPM, as expressed by one interviewee, is more concerned about what will happen to the laid infrastructure that is still operational and could suffer from any intervention, and distrusts works that do not involve their supervision. This, as will be discussed later, has been an important obstacle for the implementation of Envac's system.

\section{Naranjal's renewal project}

Starting in 2004, the city of Medellín began to reinvent itself, especially through strategic interventions in the peripheral areas, considered to be the most unsafe (Pizano Castillo [38]). Naranjal, which evolved to its present configuration by displacing residential buildings in favor of auto repair workshops and recyclable material storage, is one of the eight areas where urban renewal projects would take place in the city. These projects are called Partial Urban Renewal Plans. Naranjal is a strategically located area, although under-used from an environmental, social and economic perspective (Pizano Castillo [38]). Its renewal plan covers an area of twelve hectares, and borders the Medellín River on the east (Figure 1). This connection is crucial for the city, due to its ambitious plan to recover the river, which has been polluted and neglected since the beginning of the city's industrial development. Besides providing financial resources to the municipality for the development of these plans, EPM administers a wastewater treatment plant that 
collects and treats roughly $25 \%$ of the city's residential and industrial wastewater, and is building a larger plant to take care of the rest in the near future.

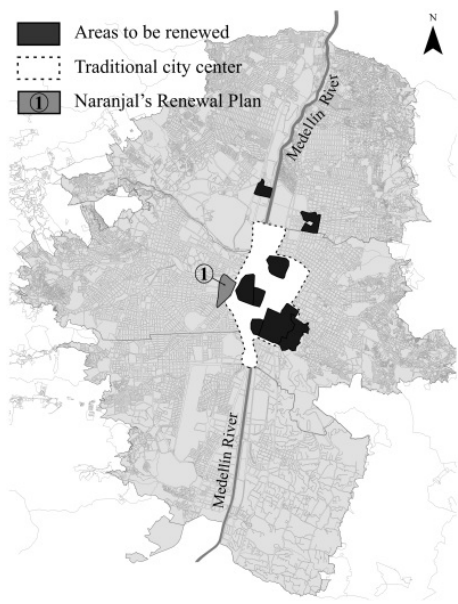

Figure 1: Location of Naranjal's renewal plan (based on the 2006 Master Plan).

\section{Envac's system in Naranjal}

Envac is a Swedish company that offers underground waste collection systems. In these systems, waste is collected through inlets embedded on the wall or cylindrical inlets installed in the street. A valve allows the waste to enter a pressurized system that sucks the bags into a central station, where they will be stored for further treatment or final disposal. Cities can benefit from an underground collection system by eliminating the need of collection trucks in dense areas or where streets are narrow, reducing emissions, and improving aesthetics and problems related to bad smells or disease vectors. Envac's system is implemented in various cities in Sweden, including an environmentally profiled neighborhood in Stockholm, called Hammarby Sjöstad. This neighborhood is a common showcase for environmental technologies in Sweden, and is a central component of this country's marketing tool to promote their urban environmental technologies, called SymbioCity (see Hult [5], Pandis Iveroth et al. [39]). Other cities in Europe have also implemented this system, including Madrid and Barcelona in Spain.

The Honorary Consul of Sweden in Colombia, who lived in Hammarby Sjöstad, was central to bringing the company to Medellín. Although this neighborhood in Stockholm was an inspiration, it is the office in Madrid which is in charge of this project. Colombia (and Latin America in general) has cultural and political links with Spain. However, we have found that Barcelona and Madrid have an additional feature that make them better showcases than, for instance, Stockholm: urban planning and design regulations in Colombia are closely related to those in Spain, and in fact, renewal projects like the one in Naranjal are very 
similar to those of the Olympic Village (Envac's first implementation in Barcelona in the 1990s) and El Raval (where Envac's system has been in operation since 2007). Although the local media mentions that it is a Swedish system, they normally discuss implementations in Spain (see e.g. Ospina Zapata [40], Twenergy [41]). Involved actors have emphasized that although it is a foreign system, its implementation plan was conceived and designed by locals (Gómez J. [42]). Gómez J. [42] mentioned that the Swedish Ambassador to Colombia highlighted that this is one important component of Sweden's relations with the city and of the Swedish government promotion of urban sustainability concepts.

Envac's system has faced an important challenge in Naranjal. Naranjal is an old neighborhood, and a large part of its underground systems (e.g. cables and pipes), although still operational, are not mapped as well as other, more modern infrastructure in other parts of the city. This fact worries EPM, as one interviewee mentioned, because it could have negative impacts on the provision of their services, when their infrastructure suffers from installation works and operation. In addition, EPM is also in charge of the collection of the city's waste, and this would be the first area where collection would happen differently. The new systems must then be able to align to the system prevailing in most of the city (i.e. above-ground collection), and consider the important place that EPM occupies in the city's socio-technical regimes and in the heart of its citizens.

\section{The importance of the showcase city for environmental technology diffusion}

Few cities venture to undertake infrastructure plans with the use of technologies that have not been proven elsewhere. Proof-of-concept projects provide confidence and accumulated knowledge that can facilitate the connection of the new systems to existing ones (Mejía-Dugand et al. [19]). In addition, cities implementing the system in the past usually contribute incremental improvements that lubricate the implementation process, by identifying obstacles and the need to adapt certain technical or legal aspects to ensure better functioning of the system, and in many cases reducing the disturbance that building and using the new system will cause to those socio-technical systems already in place.

In this line, cities-customers find it easier to understand the functioning of the system when they can see it operating under similar conditions. Foreign imaginaries often clash with local realities, as one assistant to a forum where Sweden explained its urban projects noted: "So you are talking then about a city of 300,000 (i.e. Malmö). Bello alone (i.e. a municipality bordering Medellín in the north), has 600,000". Other participants asked, when looking at pictures from these projects: "Where are the cars and the people?" This is why, as we claimed above, inhabitants of Medellín find better cases in Barcelona and Madrid for their understanding of how the system could help them solve their waste problems, and how many changes would be required in existing infrastructure and local regulations in order to implement it successfully. 


\section{Conclusions}

As discussed, cities are competing in national and international markets for resources. Also, upgrading via technology is seen as fundamental in the modern world order (Bulu [22]). When technology implementation is planned with the involvement of locals and adapted to local conditions by considering connection and coordination with existing systems, cities can find an additional benefit. Cities appreciate the opportunity to innovate locally, and doing so with urban technologies is an undeniable opportunity to attract international attention and improve its reputation (Mejía-Dugand et al. [19]), as other innovations in the city of Medellín have proved. The "Metrocable" (i.e. a gondola lift implemented in the northern neighborhoods), and the electric escalators implemented in the west are good examples of innovative use of existing, well-proven technologies that have resulted in improvements at the local level, and in increased international attention (and with it, access to resources from international markets).

We wanted to answer two questions in this paper. First, we wanted to understand how the process of selection and implementation of foreign technologies happens in cities-customers. We found that in the case of Medellín, inspiration from projects implemented in Sweden played an important role. However, it was also seen that the city found it easier to identify the requirements for a successful implementation in cities that more closely reflect its own conditions. Barcelona and Madrid provided such an opportunity, since, besides cultural and political links between Colombia and Spain, the Colombian design and planning regulations are strongly influenced by the Spanish ones. Second, we asked how technology implementation is affected by the interaction between local and foreign urban imaginaries. We found that when technologies are exported, they carry with them requirements of a cultural, infrastructural and political nature. These traits might make the implementation process difficult, as purely technocentric approaches to technology implementation face the risk of missing out on important contextual considerations. The timely involvement of central local actors allows for the identification of obstacles and hindrances, and facilitates the alignment of foreign imaginaries with local ones. Once again, strategic proofof-concept projects play a crucial role in lubricating this process.

\section{Acknowledgements}

The authors want to thank the Swedish Governmental Agency for Innovation Systems (VINNOVA) for their financial support. The information and contacts provided by all interviewees were of great help and are greatly appreciated.

\section{References}

[1] Peñalosa, E., Politics, power, cities. In: Public Lecture Hosted by LSE Cities. 1secities.net/media/objects/events/2011-01-11-politics-power-cities, 2011. 
[2] Bulkeley, H., Betsill, M., Rethinking sustainable cities: Multilevel governance and the 'urban' politics of climate change. Environmental Politics, 14(1), pp. 42-63, 2005.

[3] Vojnovic, I., Urban sustainability: Research, politics, policy and practice. Cities, 41, pp. S30-S44, 2014.

[4] Hillman, K., Nilsson, M., Rickne, A., Magnusson, T., Fostering sustainable technologies: a framework for analyzing the governance of innovation systems. Science and Public Policy, 38(5), pp. 403-415, 2011.

[5] Hult, A., Swedish production of sustainable urban imaginaries in China. Journal of Urban Technology, 20(1), pp. 77-94, 2013.

[6] Hansson, S.O., Technology and the notion of sustainability. Technology in Society, 32, pp. 274-279, 2010.

[7] Shove, E., Walker, G., Governing transitions in the sustainability of everyday life. Research Policy, 39, pp. 471-476, 2010.

[8] Ayres, R.U., van den Bergh, J.C.J.M., Gowdy, J.M., Viewpoint: Weak versus strong sustainability, Tinbergen Institute Discussion Paper 98-103/3, 1998.

[9] Cabeza-Gautés, M., The concept of weak sustainability. Ecological Economics, 17, pp. 147-156, 1996.

[10] Huesemann, M., Huesemann, J., Techno-fix - Why technology won't save us or the environment, New Society Publishers: Canada, 2011.

[11] Boonstra, W.J., Joosse, S., The social dynamics of degrowth. Environmental Values, 22, pp. 171-189, 2013.

[12] Geels, F.W., The multi-level perspective on sustainability transitions: Responses to seven criticisms. Environmental Innovation and Societal Transitions, 1, pp. 24-40, 2011.

[13] Mejía-Dugand, S., Diffusion of environmental technology in a megacity: A case study of Mexico City, Linköping Studies in Science and Technology, Licentiate thesis No. 1574, 2013.

[14] Hodson, M., Marvin, S., Can cities shape socio-technical transitions and how would we know if they were? Research Policy, 39, pp. 477-485, 2010.

[15] Wangel, J., Hur hållbara är Hammarby Sjöstad och Norra Djurgårdsstaden?, Hållbarhetens villkor, ed. H. Teleman, Bokförlaget Arena: Malmö, pp. 86103, 2013.

[16] Kanda, W., Mejía-Dugand, S., Hjelm, O., Governmental export promotion initiatives: awareness, participation, and perceived effectiveness among Swedish environmental technology firms. Journal of Cleaner Production, http://dx.doi.org/10.1016/j.jclepro.2013.11.013, 2015.

[17] Van der Slot, A., van den Berg, W., Clean Economy, Living Planet, www.worldwildlife.org/climate/Publications/WWFBinaryitem28087.pdf.

[18] Rutherford, J., Rethinking the relational socio-technical materialities of cities and ICTs. Journal of Urban Technology, 18(1), pp. 21-33, 2011.

[19] Mejía-Dugand, S., Hjelm, O., Baas, L., Ríos, R.A., Lessons from the spread of Bus Rapid Transit in Latin America. Journal of Cleaner Production, 50, pp. 82-90, 2013. 
[20] van der Heijden, J., Governance for urban sustainability and resilience. Responding to climate change and the relevance of the built environment, Edward Elgar Publishing: Cheltenham, 2014.

[21] Fukuyama, F., What is governance? Governance: An International Journal of Policy, Administration, and Institutions, 26(3), pp. 347-368, 2013.

[22] Bulu, M., Upgrading a city via technology. Technological Forecasting and Social Change, 89, pp. 63-67, 2014.

[23] DiGaetano, A., Strom, E., Comparative urban governance. An integrated approach. Urban Affairs Review, 38(3), pp. 356-395, 2003.

[24] Timms, J., Urban transport policy transfer: "bottom-up" and "top-down" perspectives. Transport Policy, 18, pp. 513-521, 2011.

[25] Polk, M., Institutional capacity-building in urban planning and policymaking for sustainable development: Success or failure? Planning Practice \& Research, 26(2), pp. 185-206, 2011.

[26] Smith, A., Stirling, A., Social-ecological resilience and socio-technical transitions: critical issues for sustainability governance, STEPS Working paper 8. STEPS Centre, Brighton, 2008.

[27] World Business Council for Sustainable Development, Mobility for Development, .aspx?id=45, 2009.

[28] Loorbach, D., Transition management for sustainable development: A prescriptive, complexity-based governance framework. Governance: An International Journal of Policy, Administration, and Institutions, 23(1), pp. 161-183, 2010.

[29] Rogers, E.M., Diffusion of Innovations $5^{\text {th }}$ ed., Free Press: New York, 2003.

[30] Oettingen, G., Mayer, D., The motivating function of thinking about the future: Expectations versus fantasies. Journal of Personality and Social Psychology, 83(5), pp. 1198-1212, 2002.

[31] Kappes, H.B., Oettingen, G., Positive fantasies about idealized futures sap energy. Journal of Experimental Social Psychology, 47, pp. 719-729, 2011.

[32] Rogers, E.M., Medina, U.E., Rivera, M.A., Wiley, C.J., Complex adaptive systems and the diffusion of innovations. The Innovation Journal: The Public Sector Innovation Journal 10(3), article 29, 2005.

[33] Furlong, K., Growing the multi-utility: The rise and expansion of the Empresas Públicas de Medellín (EPM), International Roundtable Conference, Tutzing, Germany, 2014.

[34] The Colombian Government, Order no. 1816 (July 1st), 1955.

[35] The Administrative Council of the City of Medellín, Agreement no. 58 (August 6th), 1955.

[36] Varela Barrios, E., Estrategias de expansión y modos de gestión en Empresas Públicas de Medellín. Estudios Políticos, 36, pp. 141-165, 2010.

[37] Vélez Álvarez, L.G., Evolución de las empresas de agua y saneamiento de Medellín y Cali en Colombia: ¿vidas paralelas?, Inter-American Development Bank, Nota Técnica \#IDB-TN-517, 2013. 
[38] Pizano Castillo, M., Renovación urbana: planes, instrumentos, actores y el operador urbano. Estudio comparativo de las experiencias en Barcelona y Medellin, Master's thesis, Universitat Politècnica de Catalunya, 2012.

[39] Pandis Iveroth, S., Vernay, A., Mulder, K.F., Brandt, N., Implications of systems integration at the urban level: the case of Hammarby Sjöstad, Stockholm. Journal of Cleaner Production, 48, pp. 220-231, 2013.

[40] Ospina Zapata, G., Medellín, a la vanguardia en tratamiento de basuras, El Colombiano, www.elcolombiano.com/medellin_a_la_vanguardia_en_ tratamiento_de_basuras-HCEC_256203, 2013.

[41] Twenergy, Medellín, lista para liderar el tratamiento de basuras. twenergy.com/a/medellin-lista-para-liderar-el-tratamiento-de-basuras1011, 2013.

[42] Gómez J., C.M., Suecia asesora sistema de recolección de basuras para el Plan de Naranjal, El Colombiano, www.elcolombiano.com/ suecia_asesora_sistema_de_recoleccion_de_basuras_para_el_plan_de_nar anjal-HEEC_238395, 2013. 